\title{
Nested polymerase chain reaction for detection of Enterocytozoon salmonis genomic DNA in chinook salmon Oncorhynchus tshawytscha
}

\author{
Jeffrey E. Barlough ${ }^{1,2}$, Terry S. McDowell ${ }^{1}$, Alessandra Milani ${ }^{1}$, Luisa Bigornia ${ }^{2}$, \\ Susan B. Slemenda ${ }^{3}$, Norman J. Pieniazek ${ }^{3}$, Ronald P. Hedrick ${ }^{1, *}$ \\ ${ }^{1}$ Department of Medicine and Epidemiology, School of Veterinary Medicine, and ${ }^{2}$ Department of Medical Pathology, \\ School of Medicine, University of California, Davis, California 95616-8737, USA \\ ${ }^{3}$ Division of Parasitic Diseases, National Center for Infectious Diseases, Centers for Disease Control and Prevention, \\ Mailstop F13, Atlanta, Georgia 30341-3724, USA
}

\begin{abstract}
A nested polymerase chain reaction (PCR) was developed for detection of the microsporidian parasite Enterocytozoon salmonis in biological samples (blood buffy-coat cells, feces, tissues, lymphocyte cultures) of chinook salmon Oncorhynchus tshawytscha. A major second-round PCR product of $407 \mathrm{bp}$ was readily identifiable in ethidium bromide-stained agarose minigels. An internal probe was used to verify the identity of the amplified product by non-radioactive (digoxigeninbased) Southern blotting; final confirmation was made by DNA sequence analysis. A dilution study using infected lymphocytes from in vitro cultures indicated that a single round of PCR (35 cycles) was able to detect E. salmonis DNA from approximately 1000 infected cells. Sensitivity was increased with the full nested PCR ( 35 additional cycles), which detected parasite DNA from $\leq 10$ infected lymphocytes. The specificity of the PCR was assessed with a panel of microsporidian and myxosporean DNAs. In an experimental infection study, E. salmonis DNA was detected in blood, feces, and tissues of infected chinook salmon but not in uninfected control fish.
\end{abstract}

KEY WORDS: Enterocytozoon salmonis - Microsporida. Fish diseases Oncorhynchus tshawtscha Salmon Polymerase chain reaction

\section{INTRODUCTION}

Enterocytozoon salmonis is an intranuclear microsporidian parasite of salmonids that has been associated with losses in chinook salmon Oncorhynchus tshawytscha in California, Washington, Oregon, and Idaho in the USA (Elston et al. 1987, Hedrick et al. 1990, Morrison et al. 1990, MacConnell et al. 1991) and in British Columbia, Canada (Kent et al. 1990). Additional Enterocytozoon spp. have been identified in lumpfish Cyclopterus lumpus in eastern Canada (Mullins et al. 1994) and halibut Hippoglossus hippoglossus larvae in Norway (Nilsen et al. 1995). In

-Addressee for correspondence;

E-mail: rphedrick@ucdavis.edu adult and juvenile chinook, E. salmonis infection is characterized by anemia and a chronic, severe lymphoblastosis with features of leukemia. The pathological features of the disease are similar to those of a plasmacytoid leukemia of possible viral origin that has been reported in seawater-reared chinook from British Columbia (Kent et al. 1990, Eaton \& Kent 1992, Eaton et al. 1994).

A detailed electron-microscopic study by Chilmonczyk et al. (1991) identified the major cell type infected by Enterocytozoon salmonis as a hematopoietic stem cell (lymphoblast), although several other cell types were also found to be susceptible. The intranuclear location of the parasite in lymphocytic cells, its larger spore size, and the larger number of polar-tube coils (I. Desportes-Livage, S. Chilmonczyk, R. Hedrick, C. 
Ombrouck, D. Monge, et al. unpubl.) clearly distinguish $E$. salmonis from the other recognized member of the genus, Enterocytozoon bieneusi, an intestinal microsporidian believed to cause diarrhea in humans with acquired immune deficiency syndrome (AIDS) (Desportes et al. 1985, Cali \& Owen 1990, Eeftinck Schattenkerk et al. 1991).

The natural mode of transmission of Enterocytozoon salmonis has not yet been determined. Transmission has been accomplished experimentally by feeding infected tissues and by cohabitation of uninfected fish with experimentally infected fish (Baxa-Antonio et al. 1992). Such results suggest that the parasite may be spread by indirect contact between healthy and infected fish in crowded ponds or net pens, by direct ingestion of spores excreted into the water in feces or urine, or by cannibalism.

Until now diagnosis of Enterocytozoon salmonis infection has relied solely on microscopic identification of intranuclear stages of the parasite in stained kidney imprints or tissue sections (Hedrick et al. 1990, 1991). Here we report the development of a nested polymerase chain reaction (PCR) for detection of $E$. salmonis in blood buffy-coat cells, tissues, and feces of infected fish. The nested PCR uses 2 pairs of oligonucleotide primers to amplify a portion of the $16 \mathrm{~S}$ small subunit ribosomal RNA (srRNA) gene of the parasite. The final amplification product of 407 bp can be readily visualized in ethidium bromide-stained agarose minigels. Validation of the PCR was accomplished by non-radioactive Southern blotting using an internal probe and by DNA sequence analysis of the amplified PCR product.

\section{MATERIALS AND METHODS}

Oligonucleotide design and synthesis. Two pairs of oligonucleotide primers and an oligonucleotide probe (Table 1) were designed using recently derived sequence data (1275 bp) for the srRNA gene of Enterocytozoon salmonis (N.J. Pieniazek \& R.P. Hedrick 1994, GenBank accession no. U10883) and a commercially available software package (Amplify; University of Wisconsin, Madison, WI). The oligonucleotides were synthesized on a model 394 high-throughput DNA/ RNA synthesizer (Applied Biosystems, Foster City, CA) by the phosphoramidite method.

Nested PCR. Amplification was carried out in a thermal cycler (Perkin Elmer Cetus, Norwalk, CT) and the $\mathrm{PCR}$ products were visualized in $1.5 \%$ agarose minigels, as outlined in Table 2 . The software program predicted a first-round (PCR I) product of $1093 \mathrm{bp}$ (including 3'-A overhangs) and a nested, secondround (PCR II) product of $407 \mathrm{bp}$. Appropriate internal controls were included in each PCR run.
Table 1. Oligonucleotide primers and internal probe for Enterocytozoon salmonis nested polymerase chain reaction (PCR) and Southern blotting

\begin{tabular}{|lc|}
\hline \multicolumn{3}{|c}{$5^{\prime} \rightarrow 3^{\prime}$ sequence $^{d}$} & Location $^{a}$ \\
\hline Outer primers & \\
ES-1a CTTTGTGAACCCAGACGGG & $57-75$ \\
ES-2a TGCCTTAGTGAGACACTGTTAC & $1147-1126$ \\
Inner primers & \\
ES-3a GACATTCTCTGTCCAGCGG & $690-708$ \\
ES-4a GAGCTAATCCTGCTCATCC & $1094-1076$ \\
Internal probe \\
ES-R CCATGCACCACTCTCGTTCCC \\
a Based on sequence data for the srRNA gene of E. salmo- \\
nis (N. J. Pieniazek \& R. P. Hedrick 1994, GenBank acces- \\
sion. no. U10883)
\end{tabular}

Non-radioactive Southern blotting. The oligonucleotide probe ES-R was used to verify the identity of the 407 bp PCR II product by Southern blotting, essentially as described (Barlough et al. 1994, 1995). A nonradioactive, digoxigenin (DIG)-based system was employed (Genius ${ }^{\mathrm{TM}}$; Boehringer Mannheim, Indianapolis, IN) (Martin et al. 1990). Individual aliquots of approximately 130 to $180 \mathrm{pmol}$ of probe were 3 '-end labelled with DIG-11-ddUTP using terminal trans-

Table 2. Nested PCR for Enterocytozoon salmonis: components and conditions

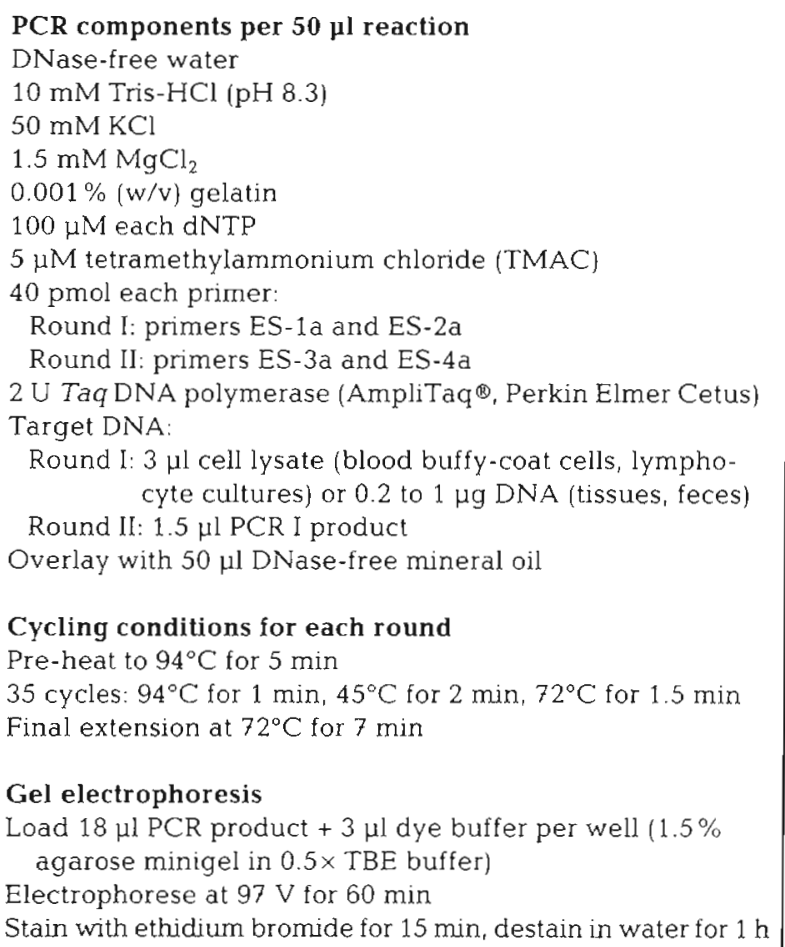


ferase. Prehybridization (in $8 \mathrm{ml} 5 \times \mathrm{SSC}, 0.1 \% \mathrm{~N}$ lauroylsarcosine, $0.02 \%$ SDS, $1 \%$ Genius ${ }^{T M}$ blocking reagent) was performed for $2 \mathrm{~h}$ at $50^{\circ} \mathrm{C}$, and was followed by overnight hybridization $\left(50^{\circ} \mathrm{C}\right)$ in $8 \mathrm{ml}$ prehybridization solution containing 1 aliquot of labelled probe. Bands were visualized by a colorimetric method (Martin et al. 1990). After blotting the probe solutions were kept at $-20^{\circ} \mathrm{C}$ for repeated use.

Cloning and sequencing of the PCR II product. The 407 bp PCR II product was cloned using the pCR ${ }^{\text {TMII }}$ vector and INV $\alpha F^{\prime}$ competent Escherichia coli (TA Cloning ${ }^{(8)}$ Kit, Invitrogen Corp., San Diego, CA) according to the manufacturer's directions. Doublestranded maxiprep DNA was isolated with a QIAGENtip 500 Plasmid Maxi Kit (QIAGEN, Chatsworth, CA). Sequencing across the insert was performed with a Sequenase $^{\mathrm{TM}} 2.0$ kit (United States Biochemical, Cleveland, OH), using $\left[\alpha-{ }^{35} \mathrm{~S}\right] \mathrm{dATP}$ and the Sp6 and T7 sequencing primers. The generated sequence was aligned with the 1275 bp sequence from the Enterocytozoon salmonis srRNA using computer software.

Detection threshold of the PCR. Cultured lymphocytes infected with Enterocytozoon salmonis (Wongtavatchai et al. 1994) were diluted to a starting concentration of $10^{5}$ infected lymphocytes PCR reaction ${ }^{-1}$. From this a series of 10 -fold dilutions was prepared and tested by PCR to determine the minimum number of infected lymphocytes needed to obtain a positive signal.

Specificity of the PCR. DNA samples from a number of microsporidian and myxosporean parasites were tested to examine the specificity of the PCR primers Phagemid clones (pBluescript ${ }^{\circledR}$, Stratagene) with inserts of the srRNA genes from Glugea atherinae, 4 species of Nosema ( $N$. corneum, N. necatrix, N. trichoplusiae, $N$. vespulae), Encephalitozoon cuniculi, Encephalitozoon hellem, Encephalitozoon (Septata) intestinalis, Pleistophora sp., and Enterocytozoon bieneusi were from the collection of Dr N.J. Pieniazek at the Centers for Disease Control and Prevention. A sample of Loma salmonae in gill tissue of chinook salmon was provided by Dr M. L. Kent, Department of Fisheries and Oceans, Pacific Biological Station, Nanaimo, British Columbia, Canada. DNA from Pleistophora anguillarum was supplied by Dr C. F. Lo, Department of Zoology, National Taiwan University, Taipei, Taiwan, R.O.C. Myxosporean samples were obtained from $\mathrm{Mr}$ $\mathrm{K}$. Andree (Ceratomyxa shasta and Myxobolus cerebralis) and Ms T. S. McDowell (Henneguya sp. from catfish) in the laboratory of Dr R. P. Hedrick at the University of California, Davis. Genomic DNA from tissue samples was extracted as described below for chinook salmon tissues.

Lymphocyte cultures. Lymphocytes from blood, spleen, and fore kidney were cultured individually from each fish (Wongtavatchai et al. 1994). The total numbers of cells and percent infection were determined as described (Wongtavatchai et al. 1994).

Experimental infections. Kidney, spleen, and peripheral blood samples from infected chinook salmon were cultured in vitro for $1 \mathrm{wk}$ as described elsewhere (Hedrick et al. 1991, Wongtavatchai et al. 1994). The cultures were then pooled, and $0.1 \mathrm{ml}$ (ca $10^{6}$ cells) of the mixture was given by intraperitoneal injection to each of six 19 mo old chinook salmon. Six salmon that had been reared from eggs in the laboratory and had no known exposure to Enterocytozoon salmonis served as uninoculated controls.

Sample preparation. Blood $(1 \mathrm{ml})$ was collected from the caudal artery into sodium heparin. Mononuclear cells were recovered from the buffy coat by density-gradient centrifugation $(1000 \times g$ for $30 \mathrm{~min}$ at $15^{\circ} \mathrm{C}$ ) through a cushion of Ficoll-Paque (Pharmacia Biotech, Piscataway, NJ). The cells were washed twice in minimum essential medium (MEM) and once in sterile phosphate-buffered saline (PBS), diluted in $200 \mu$ lysis buffer $110 \mathrm{mM}$ Tris hydrochloride ( $\mathrm{pH} 8.3$ ), $0.45 \%$ NP-40, $0.45 \%$ Tween $20,50 \mu g$ proteinase $\mathrm{K}$ $\mathrm{ml}^{-1}$ ], and incubated in a $56^{\circ} \mathrm{C}$ water bath for $3 \mathrm{~h}$. The proteinase $\mathrm{K}$ was subsequently inactivated by incubating the samples at $97^{\circ} \mathrm{C}$ for $15 \mathrm{~min}$ (Barlough et al. 1994)

Tissue and fecal samples were collected postmortem from 4 of 6 infected fish and 4 of 6 uninfected control fish and were frozen immediately at $-70^{\circ} \mathrm{C}$. Portions of the following tissues were obtained: skin, gill, liver, heart, spleen, fore kidney, hind kidney, stomach, lower intestine, pyloric cecae, gonad, and brain. The samples were processed for PCR by phenolchloroform extraction, essentially as described (Barlough et al. 1993, 1994). The DNA concentration was assessed by absorbance at $260 \mathrm{~nm}$, and the working concentration was adjusted to $0.2-1 \mu \mathrm{g}$ DNA for each $\mathrm{PCR}$ reaction.

\section{RESULTS}

\section{Development of the PCR}

Two rounds of amplification resulted in the appearance of the predicted $407 \mathrm{bp}$ PCR II product in agarose minigels (Fig. 1A). Preliminary verification of identity was made by non-radioactive Southern blotting (Fig. 1B). For definitive verification the PCR II product was sequenced and identified as an Enterocytozoon salmonis srRNA gene fragment by alignment with the previously derived sequence data (N. J. Pieniazek \& R. P. Hedrick 1994, GenBank accession no. U10883). 


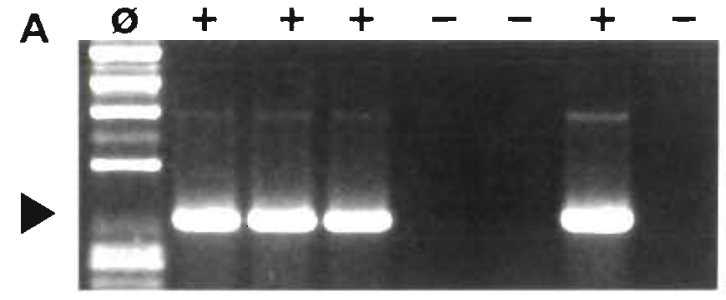

B

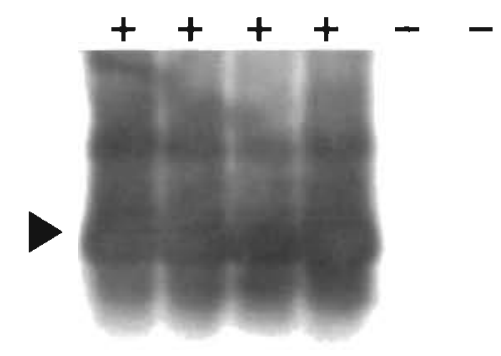

Fig. 1. Enterocytozoon salmonis and Oncorhynchus tshawytscha. (A) E. salmonis nested PCR using DNA from blood buffy-coat cells from 4 infected $(+)$ and 3 uninfected $(-)$ chinook salmon. Arrowhead indicates position of the $407 \mathrm{bp}$ PCR II product. ø: øX174 RF DNA-HaellI digest. (B) Digoxigenin-based Southern blot of amplified DNA from blood buffy-coat cells from 4 infected $(+)$ and 2 uninfected (-) chinook salmon. Arrowhead indicates position of the $407 \mathrm{bp}$ PCR II product

\section{Detection threshold of the PCR}

Analysis of dilutions of cultured lymphocytes indicated that DNA from 1000 infected lymphocytes was needed to detect Enterocytozoon salmonis when only the first round of PCR, using the outer primers, was performed (Fig. 2, top). With the full nested PCR, however, DNA originating from $\leq 10$ infected lymphocytes was sufficient to generate a PCR signal (Fig. 2, bottom).
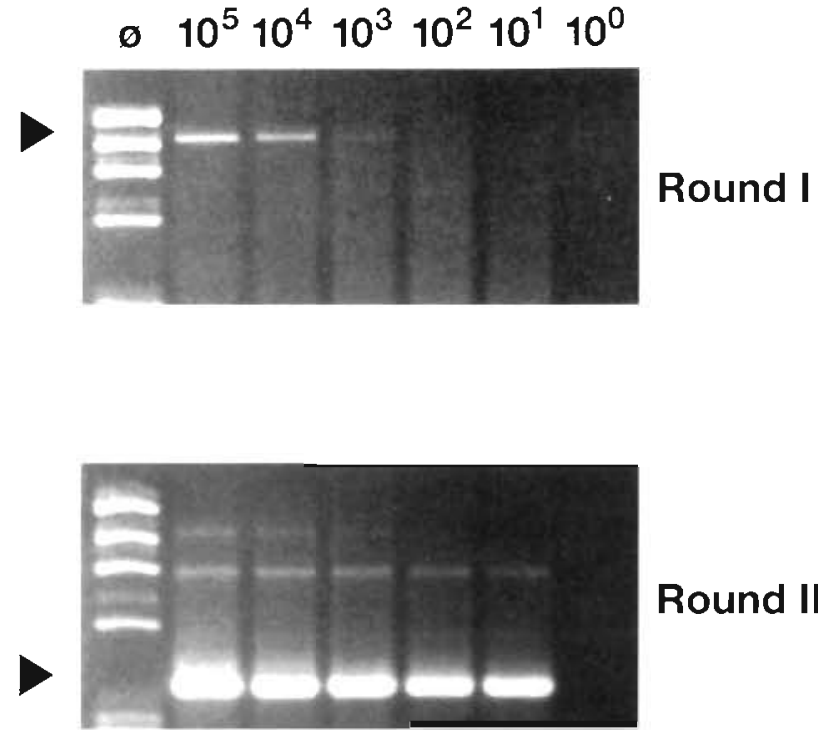

Round II

Fig. 2. Enterocytozoon salmonis and Oncorhynchus tshawytscha. Detection threshold of the nested PCR for E. salmonis DNA in cultured chinook salmon lymphocytes. The number of infected lymphocytes serving as the source of DNA for each PCR reaction is shown above each lane. Arrowheads indicate positions of the $1093 \mathrm{bp}$ PCR I (top) and 407 bp PCR II (bottom) products. ø: $₫$ X 174 RF DNA-HaeIII digest

\section{Specificity of the PCR}

For the 13 microsporidians and 3 myxosporeans examined, a PCR signal was obtained only with Enterocytozoon salmonis and Nosema necatrix, a microsporidian parasite of phytophagous insects (Fig 3). Among the organisms tested, therefore, no fish parasite other than E. salmonis was detected with the current primer set. Interestingly, the primers were capable of distinguishing between $E$. salmonis and the only other known member of the genus, $E$. bieneusi, an intestinal microsporidian found in AIDS patients.

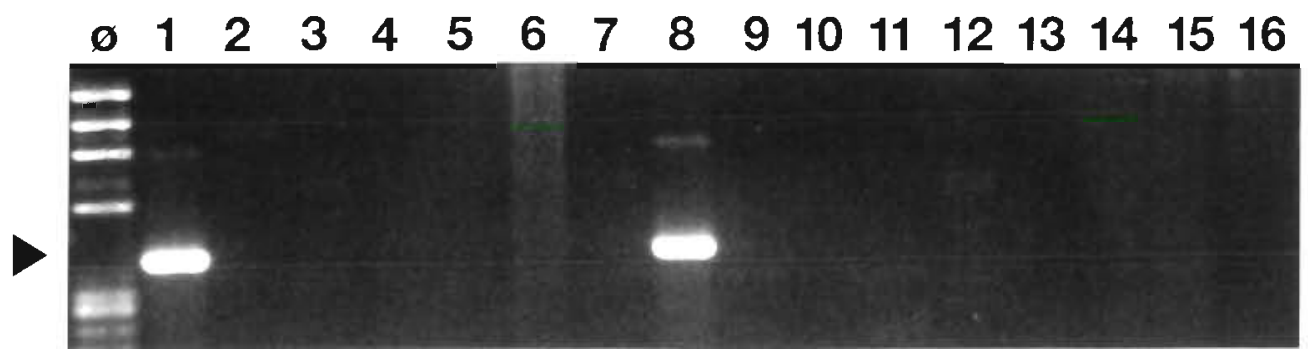

Fig. 3. Specificity of the nested PCR, using DNA from different microsporidian and myxosporean parasites. Numbered samples are: 1, Enterocytozoon salmonis; 2 , Enterocytozoon bieneusi $i_{i}$, Encephalitozoon cuniculi 4 , Encephalitozoon hellem; 5 , Glugea atherinae; 6, Loma salmonae; 7. Nosema corneum; 8, Nosema necatrix; 9, Nosema trichoplusiae; 10, Nosema vespulae; 11. Pleistophora sp.; 12, Pleistophora anguillarum; 13, Encephalitozoon (Septata) intestinalis; 14, Ceratomyxa shasta; 15, Henneguya sp.; 16, Myxobolus cerebralis. Arrowhead indicates position of the 407 bp PCR II product. $\bullet$ : $\bullet$ X174 RF DNA-HaellI digest 


\section{Experimental infection study}

Blood buffy-coat cells from experimentally infected fish were positive for Enterocytozoon salmonis by PCR, while equivalent cells from uninfected control fish were negative (Table 3). Most sampled tissues from infected fish generated PCR signals, while tissues from uninfected control fish were negative without exception. Feces were also positive in all 4 infected fish tested.

A comparison of results obtained by PCR and light microscopic examination of blood, spleen, and kidney cells is shown in Table 4. The percentage of cells infected with Enterocytozoon salmonis, as determined by direct light microscopic examination, ranged from 10 to $69 \%$ for blood, 11 to $73 \%$ for spleen, and 13 to $83 \%$ for kidney. All samples found positive by light microscopic examination were also positive by PCR. The 3 fish with the highest percentages of visibly parasitized cells had the highest percentages of PCRpositive tissues ( 86 to $93 \%$ ), while the fish with the lowest percentage of parasitized cells (no. 11) had the lowest percentage of PCR-positive tissues (71\%). E. salmonis was not detected in blood buffy-coat or tissue samples from uninfected control fish.

\section{DISCUSSION}

In this paper we have described the development of a nested PCR for the detection of Enterocytozoon salmonis in blood buffy-coat cells, tissues, feces, and lymphocyte cultures of chinook salmon. The assay relies on 2 sets of oligonucleotide primers to amplify a $407 \mathrm{bp}$ fragment of the $16 \mathrm{~S}$ srRNA gene of the parasite.

Table 3. Enterocytozoon salmonis experimental infection study PCR results on blood buffy-coat cells, tissues, and feces. + : strong positive $e_{i}+$-: weak positive; -: negative

\begin{tabular}{|lccccccccc|}
\hline \multirow{3}{*}{ Samples } & \multicolumn{3}{c}{ Infected fish } & \multicolumn{3}{c}{ Control fish } \\
& 9 & 10 & 11 & 12 & 3 & 4 & 5 & 6 \\
\hline Blood buffy-coat & + & $+/-$ & + & + & - & - & - & - \\
Skin & - & - & - & + & - & - & - & - \\
Gill & $+/-$ & + & - & $+/-$ & - & - & - & - \\
Liver & + & + & - & + & - & - & - & - \\
Heart & + & + & + & + & - & - & - & - \\
Spleen & + & + & + & + & - & - & - & - \\
Fore kidney & + & + & + & + & - & - & - & - \\
Hind kidney & + & + & + & $+/-$ & - & - & - & - \\
Stomach & + & + & + & + & - & - & - & - \\
Lower intestine & + & $+/-$ & + & $+1-$ & - & - & - & - \\
Pyloric cecae & $+/-$ & $+1-$ & - & - & - & - & - & - \\
Gonad & + & + & + & - & - & - & - & - \\
Brain & + & + & + & $+/-$ & - & - & - & - \\
Feces & $+/-$ & + & + & $+/-$ & - & - & - & - \\
\hline
\end{tabular}

Table 4. Enterocytozoon salmonis experimental infection study. Comparison of results obtained by PCR and light microscopic examination of blood (buffy-coat cells) and tissues from infected fish. + : strong positive; $+/-$ : weak positive

\begin{tabular}{|c|c|c|c|c|}
\hline Fish no. & $\begin{array}{l}\text { Tissue } \\
\text { examined }\end{array}$ & $\begin{array}{l}\% \text { of cells } \\
\text { infected }\end{array}$ & $\begin{array}{l}\text { PCR } \\
\text { result }\end{array}$ & $\begin{array}{l}\% \text { of all tissues } \\
\text { PCR-positive }\end{array}$ \\
\hline \multirow[t]{3}{*}{9} & Blood & 69 & + & \multirow{3}{*}{93} \\
\hline & Spleen & 73 & + & \\
\hline & Kidney & 76 & + & \\
\hline \multirow[t]{3}{*}{10} & Blood & 27 & $+1-$ & \multirow{3}{*}{93} \\
\hline & Spleen & 33 & + & \\
\hline & Kidney & 53 & + & \\
\hline \multirow[t]{3}{*}{11} & Blood & 10 & + & \multirow{3}{*}{71} \\
\hline & Spleen & 11 & + & \\
\hline & Kidney & 13 & + & \\
\hline \multirow[t]{3}{*}{12} & Blood & 23 & + & \multirow{3}{*}{86} \\
\hline & Spleen & 68 & + & \\
\hline & Kidney & 83 & + & \\
\hline \multicolumn{5}{|c|}{$\begin{array}{l}\text { "As determined by light microscopic examination } \\
\text { "For each fish this represents the percentage of the } 14 \text { total } \\
\text { samples (tissues, blood buffy-coat cells, and feces) that } \\
\text { were positive by the nested PCR, as shown in Table } 3\end{array}$} \\
\hline
\end{tabular}

The advantages of a nested PCR include direct visualization of specific bands in ethidium bromide-stained minigels, enhanced sensitivity by an increase in the cumulative number of amplification cycles, and elimination of the need for Southern blotting (which is often required to obtain reasonable sensitivity with a singleround PCR). By serving essentially as a pair of internal probes, the inner primers act on the amplified DNA. from the first PCR round to generate the second, nested fragment. Thus, the specificity of the reaction is assessed by the PCR itself rather than by subsequent Southern hybridization.

Diagnosis of Enterocytozoon salmonis infection currently relies on microscopic identification of intranuclear stages of the parasite in stained kidney imprints or tissue sections (Hedrick et al. 1990, 1991). However, this method often fails to detect early or light infections and presumably also infected fish that may be serving as asymptomatic carriers. Moreover, obtaining the appropriate tissue samples for parasite detection necessitates sacrificing the fish. The PCR described here affords an opportunity to examine non-terminal samples such as blood or feces, which becomes particularly important when larger fish of high market value or potential brood stocks are involved. Field studies are now underway to evaluate the PCR as a screening and diagnostic technique for $E$. salmonis in chinook salmon and other susceptible species. By testing and removal of infected fish it may ultimately be possible to eradicate the parasite from affected hatcheries and other commercial aquaculture facilities. 
The epizootiology of Enterocytozoon salmonis infections among salmonid fish populations is only poorly understood. The microsporidian is presumed to be a strict fish parasite, with infected fish serving as the major reservoir. Initial conjecture that $E$. salmonis might be highly related to the human pathogen $E$. bieneusi has been discounted by recent srRNA gene sequence data, which confirm relatedness but also indicate that these are clearly 2 separate microsporidian species (Hartskeerl et al. 1993, Zhu et al. 1993; N. J. Pieniazek \& R. P. Hedrick 1994, GenBank no. U10883). The intranuclear location of $E$. salmonis within lymphocytic cells, its larger spore size, and the larger number of polar-tube coils also provide clear distinguishing features (Chilmonczyk et al, 1991, DesportesLivage et al. unpubl.). It seems likely that E. salmonis represents simply the first of several aquatic members of the genus Enterocytozoon that are now being identified in different fish hosts (MacConnell et al. 1991, Mullins et al. 1994, Nilsen et al. 1995).

Initial experimental studies with Enterocytozoon salmonis have shown that 2 natural routes (cohabitation with infected fish, and the feeding of infected tissues) result in transmission of the parasite (BaxaAntonio et al. 1992). Oral ingestion of spores is presumed to be the route of entry of the infective stage. The parasite then spreads from this initial site to the major cellular targets in hematopoietic tissues, principally the spleen and kidney (Morrison et al. 1990, Hedrick et al. 1991). Infected lymphocytes can also be found in many other tissues, including the large intestine (lamina propria), heart, pancreas, liver, brain, eye, and skin. In addition, the parasite has been shown to infect non-lymphoid cells as well (Chilmonczyk et al. 1991, MacConnell et al. 1991).

PCR detection of Enterocytozoon salmonis in the feces of infected fish supports an intestinal role in excretion and shedding of the parasite, which presumably is one major route for fish-to-fish transmission. The presence of parasite DNA in virtually all tissues examined here probably reflects the systemic spread of infected lymphocytes, as demonstrated in the earlier histologic studies of Morrison et al. (1990) and Hedrick et al. (1991). Using the PCR, it should now be possible to study the distribution of the parasite early in infection and prior to the onset of clinical signs. The presence of the parasite in fish surviving experimental infections, in asymptomatic fish in hatcheries, and in the progeny of infected adults can now be examined as well. Such studies should facilitate a better understanding of host-parasite interactions and the major route(s) of transmission.

Acknowledgments. This work was supported by grant no. CSRS-93-37204-9342 from the United States Department of Agriculture; by the California Department of Fish and Game; and by discretionary funds from the Department of Medicine and Epidemiology, School of Veterinary Medicine, University of California, Davis. We thank Dr Janenuj Wongtavatchai, Mr Karl Andree, and Ms Nancy Rooijakkers for assistance at various stages of the project. A portion of this work was presented at the International Symposium on Aquatic Animal Health, 4 to 8 September 1994, in Seattle, Washington, USA.

\section{LITERATURE CITED}

Barlough J, East N, Rowe JD, Van Hoosear K, DeRock E, Bigornia L, Rimstad E (1994) Double-nested polymerase chain reaction for detection of caprine arthritis-encephalitis virus proviral DNA in blood, milk, and tissues of infected goats. J virol Methods 50:101-113

Barlough JE, Madigan JE, DeRock E, Bigornia L (1995). Nested polymerase chain reaction for detection of Ehrlichia equi genomic DNA in horses and ticks (Ixodes pacificus). Vet Parisitol (in press)

Barlough JE, North TW, Oxford CL, Remington KM, Dandekar S, Ellis MN, Pedersen NC (1993) Feline immunodeficiency virus infection of cats as a model to test the effect of certain in vitro selection pressures on the infectivity and virulence of resultant lentivirus variants. Antivir Res 22:259-272

Baxa-Antonio D, Groff JM, Hedrick RP (1992) Experimental horizontal transmission of Enterocytozoon salmonis to chinook salmon, Oncorhynchus tshawytscha. J Protozool 39:699-702

Cali A, Owen RL (1990) Intracellular development of Enterocytozoon, a unique microsporidian found in the intestine of AIDS patients. J Protozool 37:145-155

Chilmonczyk S, Cox WT, Hedrick RP (1991) Enterocytozoon salmonis n. sp.: an intranuclear microsporidium from salmonid fish. J Protozool 38:264-269

Desportes I, Le Charpentier Y, Galian A, Bernard F, CochandPriollet B, Lavergne A, Ravisse P, Modigliani R (1985) Occurrence of a new microsporidian: Enterocytozoon bieneusi n.g., n.sp., in the enterocytes of a human patient with AIDS. J Protozool 32:250-253

Eaton WD, Kent ML (1992) A retrovirus in chinook salmon (Oncorhynchus tshawytscha) with plasmacytoid leukemia and evidence for the etiology of the disease. Cancer Res 52:6496-6500

Eaton WD, Folkins B, Kent ML, Dawe S, Newbound GC, Zinkl J (1994) Preliminary analysis of the polypeptides of the salmon leukemia virus (SLV) and evidence for development of a bimodal viremia following SLV infection. Vet Microbiol 42:217-227

Eeftinck Schattenkerk JKM, van Gool T, van Ketel RJ, Bartelsman JFWM, Kuiken CL, Terpstra WJ, Reiss P (1991) Clinical significance of small-intestinal microsporidosis in HIV 1-infected individuals. Lancet 337:895-898

Elston RA, Kent ML, Harrell LH (1987) An intranuclear microsporidium associated with acute anemia in the chinook salmon, Oncorhynchus tshawytscha. J Protozool 34:274-277

Hartskeerl RA, Schuitema ARJ, van Gool T, Terpstra WJ (1993) Genetic evidence for the occurrence of extraintestinal Enterocytozoon bieneusi infections. Nucleic Acids Res 21:41.50

Hedrick RP, Groff JM, McDowell TS, Willis M, Cox WT (1990) Hematopoietic intranuclear microsporidian infections with features of leukemia in chinook salmon Oncorhynchus tshawytscha. Dis aquat Org 8:189-197

Hedrick RP, Groff JM, Baxa DV (1991) Experimental infections with Enterocytozoon salmonis Chilmonczyk, Cox, 
Hedrick (Microsporea): an intranuclear microsporidium from chinook salmon Oncorhynchus tshawytscha. Dis aquat Org 10:103-108

Kent ML, Groff JM, Traxler GS, Zinkl JG, Bagshaw JW (1990) Plasmacytoid leukemia in seawater reared chinook salmon Oncorhynchus tshawytscha. Dis aquat Org 8: 199-209

MacConnell E, Shaw T, Smith CE (1991) Naturally-occurring infection with intranuclear microsporidium Enterocytozoon salmonis in steelhead trout Oncorhynchus mykiss. Proceedings 4 th Annual AFS/FHS Meeting, 32nd Western Fish Disease Conference, Newport, Oregon, USA, 31 July-3 August, 1991, p 11

Martin R, Hoover C, Grimme S, Grogan C, Höltke J, Kessler C (1990) A highly sensitive, nonradioactive DNA labeling and detection system. BioTechniques 9:762-768

Morrison JK, MacConnell E, Chapman PF, Westgard RL (1990) A microsporidium-induced lymphoblastosis in

Responsible Subject Editor: W. Körting, Hannover, Germany chinook salmon Oncorhynchus tshawytscha in freshwater. Dis aquat Org 8:99-104

Mullins JE, Powell M, Speare DJ, Cawthorn R (1994) An intranuclear microsporidian in lumpfish Cyclopterus lumpus. Dis aquat Org 20:7-13

Nilsen F, Ness A. Nylund A (1995) Observation on an intranuclear microsporidian in lymphoblasts from farmed Atlantic halibut larvae (Hippoglossus hippoglossus L.). J eukaryot Microbiol (in press)

Wongtavatchai J, Conrad PA, Hedrick RP (1994) In vitro cultivation of the microsporidian: Enterocytozoon salmonis using a newly developed medium for salmonid lymphocytes. J Tissue Cult Meth 16:125-131

Zhu X, Wittner M, Tanowitz HB, Kotler D, Cali A, Weiss LM (1993) Small subunit rRNA sequence of Enterocytozoon bieneusi and its potential diagnostic role with use of the polymerase chain reaction. $J$ infect Dis 168: $1570-1575$

Manuscript first received: February 2, 1995

Revised version accepted: May 29, 1995 